\title{
The relationship between upper extremity strength and performance in elite amputee football players
}

Authors' Contribution: A Study Design B Data Collection C Statistical Analysis D Data Interpretation E Manuscript Preparation F Literature Search

G Funds Collection

\section{Gurkan Gunaydin}

Department of Physical Therapy and Rehabilitation, Faculty of Health Sciences, Aydın Adnan Menderes University, Efeler, Aydın, Turkey

\section{abstract}

Background: Despite having similar requirements to regular football, amputee football may also require different dynamics due to using crutches. This study investigated the relationship between upper extremity strength and performance in amputee players.

Material and methods:

Twenty amputee players participated in this study. Running performance of amputee players was measured with sprint tests; aerobic performance with a shuttle run test; jumping performance with a one-leg hop test and upper extremity strength with a digital dynamometer. The relationship between the types of performance was evaluated by multiple regression analysis.

Results: The $10(p=0.009)$ and 20 meters sprint performance $(p=0.035)$ was associated with latissimus dorsi muscle and the 30 meters $(p=0.030)$ with shoulder extension strength. In addition, $10(p=0.018)$, $20(p=0.020)$ and 30 meters sprint performance $(p=0.036)$ was associated with one-leg hop performance. However, there were no related data with the $\max \mathrm{VO}_{2}(p=0.339)$, and the aerobic performance test duration $(p=0.348)$.

Conclusions: The results indicated that the sprinting performance of amputee players was not only related with lower extremity strength but also with upper extremity strength. It may be beneficial to include shoulder extension and particularly latissimus dorsi strengthening exercises in training programs of amputee football players to provide an increase in anaerobic performance.

Key words: amputees, football, crutches, performance.

\section{article details}

Article statistics: Word count: 2,459; Tables: 4; Figures: 0; References: 37

Received: March 2020; Accepted: April 2020; Published: June 2020

Full-text PDF: http://www.balticsportscience.com

Copyright @ Gdansk University of Physical Education and Sport, Poland

Indexation: Celdes, Clarivate Analytics Emerging Sources Citation Index (ESCI), CNKI Scholar (China National Knowledge Infrastructure), CNPIEC, De Gruyter - IBR (International Bibliography of Reviews of Scholarly Literature in the Humanities and Social Sciences), De Gruyter - IBZ (International Bibliography of Periodical Literature in the Humanities and Social Sciences), DOAJ, EBSCO - Central \& Eastern European Academic Source, EBSCO - SPORTDiscus, EBSCO Discovery Service, Google Scholar, Index Copernicus, J-Gate, Naviga (Softweco, Primo Central (ExLibris), ProQuest - Family Health, ProQuest - Health \& Medical Complete, ProQuest - Illustrata: Health Sciences, ProQuest - Nursing \& Allied Health Source, Summon (Serials Solutions/ProQuest, TDOne (TDNet), Ulrich's Periodicals Directory/ulrichsweb, WorldCat (OCLC)

Funding: This research received no specific grant from any funding agency in the public, commercial, or not-for-profit sectors.

Conflict of interests: Corresponding author:

Open Access License:
Authors have declared that no competing interest exists.

Gurkan Gunaydin, Department of Physical Therapy and Rehabilitation, Faculty of Health Sciences, Aydın Adnan Menderes University, Efeler, Aydın, Turkey; Phone: +90 55472427 42; E-mail: gunaydingrkn@gmail.com; ORCID: Gurkan GUNAYDIN: https://orcid.org/0000-0003-3432-6431

This is an open access article distributed under the terms of the Creative Commons Attribution-Non-commercial 4.0 International (http://creativecommons.org/licenses/by-nc/4.0/), which permits use, distribution, and reproduction in any medium, provided the original work is properly cited, the use is non-commercial and is otherwise in compliance with the license. 


\section{INTRODUCTION}

Amputation is defined as a permanent loss of all or part of the extremity [1], and it poses a major health problem worldwide despite the technological advancements [2]. In one study, authors stated that 1.9 million people had losses of extremities in the United States as of 2006, and estimated that this number would increase more than twice by 2050 [3].

Individuals commonly experience physical and psychological problems as a result of amputation [4,5]. However, participation in sports activities contributes to the development of lower extremity amputees in physical and psychosocial terms and helps with neutralizing the negative effects of amputation [5-7]. Therefore, participation in sports activities by individuals with disabilities is encouraged [6], and many amateur and professional sports branches were created for this purpose. Amputee football, which was originally created for rehabilitation and continued its development with professional investments over time, now emerges as one of these athletic branches [8,9].

Amputee football is played by two teams of seven people (six players, one goal keeper) and in two periods, 25 minutes each [10]. The pitch in amputee football is approximately 40x60 meters and it can be synthetic or natural grass [1, 10]. Goalkeepers have two intact lower extremities, but one upper extremity amputation. Outfield players have a lower extremity amputation and they use crutches in the game. Due to the nature of the game, players cannot use their prostheses in the field and cannot get support from their amputated extremities $[10,11]$.

In amputee football, similarly to regular football, optimal flexibility, strength, endurance, speed and agility are required to perform sufficient performance $[12,13]$. However, it is important to remember that amputee football may also have different requirements, especially due to the use of crutches [14]. In scientific literature, studies have revealed a significant relationship between lower extremity strength and performance in regular football players [15, 16]. Similarly, the idea of a relationship between lower extremity strength and performance in amputee football players would be a natural outcome [17]. However, as stated, amputee athletes play with a pair of crutches, in addition to the lower extremity strength, the upper extremity strength may also be necessary for performance in amputee football players [14]. Multiple studies have been constructed upon this idea [18-20]. However, none of these studies in the literature has specifically questioned the relationship between upper extremity strength and performance in amputee football players. Therefore, the purpose of this study is to investigate the relationship between upper extremity strength and performance in elite amputee football players. This study may contribute to the literature on ever-developing amputee football, and the potential results of the study contribute to the regulation of training programs as well as development of the performance skills of amputee football players.

\section{MATERIAL AND METHODS}

\section{PARTICIPANTS}

This scientific research retrospectively used the strength and performance data obtained from amputee football players in the Turkish National Amputee Football team between August 2019 and September 2019. For this study, permission 
(No. 92340882-050.04.04; protocol 2019/085) was obtained from the Clinical Research Ethics Committee of the Faculty of Health Sciences in Aydin Adnan Menderes University dated 25.12.2019. For the study, the data obtained from 25 players, who participated in the National Team camp between the specified dates and had complete strength and performance data, were used. Since the goalkeepers had upper extremity amputation, they were excluded from the study and the data of 20 football players were used for statistical analysis. One-leg hop, sprint at 10, 20, 30 meters and shuttle run tests were used to measure players' performances. To measure strength, shoulder flexion, shoulder abduction, shoulder extension and elbow extension strengths were evaluated along with the strength of the serratus anterior, latissimus dorsi and upper trapezius muscles.

\section{TESTS}

One leg hop test

Firstly, amputee football players stood on the starting line with their hands on their waist and on their support leg without prostheses and crutches. While standing in this position, they jumped without losing their balance and lowering their hands. The distance from the starting line to the heel of the player was recorded in centimeters $[21,22]$. Players performed the test twice and the best value was taken as the result.

\section{Sprint performance}

In order to measure the amputee players' running performance, a starting line was created and every 10-meter distance was marked. The test started with a beep and sprint times of the participants at 10, 20 and 30 meters were recorded. The players did not use their prostheses during the sprint, and they ran with crutches [17]. Athletes performed the sprint test twice and the best values were taken as the result.

\section{Shuttle run test}

For the shuttle run test, two distances of 20 meters were determined and marked with cones. The test with accelerating speed started with a beep command (started with a speed of $8.5 \mathrm{~km} / \mathrm{h}-1$, and speed was accelerated by $0.5 \mathrm{~km} / \mathrm{h}$ 1 every minute) $[23,24]$. In the test, players should pass 20 meters until the other beep. The test was terminated if the participant dropped the test or could not reach the finish line before the beeps two times [23]. In this test, both the estimated maximum $\mathrm{VO}_{2}$ values of the players and their test times were calculated [24]. Before all performance tests, the details of which were explained above, the measurements were verbally and visually explained to the participants.

\section{Strength tests}

Lafayette-Manual Muscle Tester (Lafayette Instrument Company, Lafayette, USA, Model: 01165) digital dynamometer was used to measure all strength values. Before the measurement of strength, a tester explained the test content to the participants verbally and practically. The same tester repeated the strength measurements three times, and the highest values was recorded for analysis [25, 26]. For this retrospective study, previously measured upper extremity strength parameters recorded in the data form were included. These parameters were shoulder flexion, abduction, extension and elbow extension strength as well as latissimus dorsi, serratus anterior and upper trapezius muscle strengths. For shoulder flexion and abduction strength, the arm was placed in 90 degree flexion and abduction respectively while the athlete was 
in a sitting position. Resistance was given downward from the distal of the humerus. For the shoulder extension strength, the athlete was asked to lift his arm back while in the prone position. Resistance was given downward from the distal of the humerus. While the athlete was in the supine position to determine the elbow extension strength, the shoulder and elbow were brought to the 90 degree flexion position. Resistance was given downwards over the wrist. For the latissimus dorsi strength, while the participant was in a sitting position, the elbow was brought to 90 degrees of flexion, the shoulder internal rotation and 30 degrees extension. The resistance was applied to the posterior aspect of the upper arm over the elbow. While the athlete was in the supine position for the strength of the serratus anterior, the elbow was placed full and the shoulder at 90 degrees flexion. Resistance was applied over olecranon while the athlete was performing shoulder protraction. Finally, the participant was placed in a sitting position to determine the strength of the upper trapezius muscle. While the athlete tried to elevate the shoulder against resistance, the dynamometer was applied to the head that laterally flexed. For each strength test maximum resistance was applied for 3-5 seconds with dynamometer, and the values were recorded as Newton [25, 27, 28].

\section{STATISTICAL ANALYSIS}

The normality analyses of the data obtained for the study were evaluated using visual (histograms, probability plots) and analytical methods (Shapiro Wilk's test). As a result of the analysis, it was seen that all data had normal distribution. Multiple regression analysis was used to determine the performance and upper extremity strength association level in amputee players, and statistical significance value was determined as $\mathrm{p}<0.05$ for all data.

\section{RESULTS}

The average age of the Turkish National Amputee Football Players that participated in the study was $25.55 \pm 5.17$ years, and their average weights were $64.93 \pm 8.11 \mathrm{~kg}$. Other demographic information and detailed performance/ strength results of the players were summarized in Table 1.

As a result of multiple regression analysis performed to determine the association between upper extremity strength and performance in elite amputee players, a significant interaction was found between sprint performances at 10 meters $(p=$ $0.009, p=0.018), 20$ meters $(\mathrm{p}=0.035, \mathrm{p}=0.020)$ and latissimus dorsi strength, one leg hop performance respectively. There was a significant correlation of shoulder extension strength $(p=0.030)$ and one leg hop performance $(p=0.036)$ with 30 meters sprint (Table 2).

As a result of the shuttle run test, none of the upper extremity data had an association with max $\mathrm{VO}_{2}$ consumption $(\mathrm{p}=0.339)$ or shuttle run test time $(\mathrm{p}$ $=0.348$ ) (Table 3 ). In addition, the independent variables did not have any multicollinearity with each other (Table 2) [29].

As stated before, athletes performed sprint and one-leg hop tests twice and the strength tests 3 times, and the highest values were recorded for analysis. ICC results obtained from these data varied between 0.579-0.951 (Table 4). 
Table 1. Demographic, performance and strength data of the amputee players

\begin{tabular}{cc}
\hline & Mean \pm SD \\
\hline Age (year) & $25.55 \pm 5.17$ \\
Height (cm) & $175.40 \pm 5.81$ \\
Weight (kg) & $64.93 \pm 8.11$ \\
10m sprint (s) & $2.20 \pm 0.22$ \\
20m sprint (s) & $3.81 \pm 030$ \\
30m sprint (s) & $5,37 \pm 0.41$ \\
Shuttle run test duration (s) & $304.60 \pm 71.19$ \\
MaxVO $(\mathrm{ml} / \mathrm{kg} / \mathrm{mn})$ & $32.43 \pm 3.95$ \\
OLH (cm) & $214.70 \pm 13.50$ \\
S.Flex (N) & $236.39 \pm 36.74$ \\
S.Ext (N) & $184.46 \pm 30.50$ \\
S.Abd (N) & $238.06 \pm 32.75$ \\
E.Eks (N) & $201.18 \pm 22.30$ \\
S.Anterior (N) & $186.28 \pm 24.94$ \\
L.Dorsi (N) & $183.14 \pm 27.93$ \\
U.Trapezius (N) & $173.68 \pm 22.26$ \\
\hline
\end{tabular}

$\mathrm{MaxVO}_{2}$ : Shuttle run test approximate maximal oxygen consumption, OLH: One leg hop test, S.Flex: Shoulder flexion strength, S.Ext: Shoulder extension strength, S.Abd: Shoulder abduction strength, E.Ext: Elbow extension strength, S.Anterior: Serratus anterior muscle strength, L.Dorsi: Latissimus dorsi muscle strength, U.Trapezius: Upper trapezius muscle strength.

Table 2. Multiple regression analyses of the sprint performances

\begin{tabular}{|c|c|c|c|c|c|c|c|}
\hline DV & IV & Adjusted $\mathrm{R}^{2}$ & $\beta$ & $\mathrm{t}$ & $p$ & $95 \% \mathrm{Cl}$ & VIF \\
\hline \multirow{2}{*}{$\begin{array}{l}10 \mathrm{~m} \\
\text { sprint }\end{array}$} & L.Dorsi & \multirow{2}{*}{0.503} & -0.492 & -2.928 & 0.009 & $\begin{array}{l}-0.007 / \\
-0.001\end{array}$ & 1.081 \\
\hline & OLH & & -0.440 & -2.618 & 0.018 & $\begin{array}{l}-0.013 / \\
-0.001\end{array}$ & 1.081 \\
\hline \multirow{2}{*}{$\begin{array}{l}20 \mathrm{~m} \\
\text { sprint }\end{array}$} & L.Dorsi & \multirow{2}{*}{0.430} & -0.413 & -2.294 & 0.035 & $\begin{array}{l}-0.009 / \\
-0.000\end{array}$ & 1.081 \\
\hline & $\mathrm{OLH}$ & & -0.463 & -2.571 & 0.020 & $\begin{array}{l}-0.019 / \\
-0.002\end{array}$ & 1.081 \\
\hline \multirow{2}{*}{$\begin{array}{l}30 \mathrm{~m} \\
\text { sprint }\end{array}$} & S.Ext & \multirow{2}{*}{0.393} & -0.436 & -2.367 & 0.030 & $\begin{array}{l}-0.011 / \\
-0.001\end{array}$ & 1.064 \\
\hline & $\mathrm{OLH}$ & & -0.420 & -2.277 & 0.036 & $\begin{array}{l}-0.025 / \\
-0.001\end{array}$ & 1.064 \\
\hline
\end{tabular}

DV: Dependent variable, IV: Independent variable, $\beta$ : Standardized coefficient, L.Dorsi: Latissimus dorsi muscle strength, S.Ext: Shoulder extension strength, OLH: One leg hop test.

Table 3. Multiple regression analyses of the aerobic performance

\begin{tabular}{|c|c|c|c|c|}
\hline DV & IV & Adjusted $\mathrm{R}^{2}$ & $\mathrm{~F}$ & $p$ \\
\hline Test duration & $\begin{array}{c}\text { Strength* } \\
\text { OLH }\end{array}$ & 0.102 & 1.270 & 0.348 \\
\hline $\mathrm{MaxVO}_{2}$ & $\begin{array}{c}\text { Strength* } \\
\text { OLH }\end{array}$ & 0.109 & 1.291 & 0.339 \\
\hline
\end{tabular}

DV: Dependent variable, IV: Independent variable, Test duration: Shuttle run test duration of the players, $\mathrm{MaxVO}_{2}: \mathrm{OLH}$ One leg hop test, Strength*: Shoulder flexion strength, shoulder extension strength, shoulder abduction strength, elbow extension strength, serratus anterior muscle strength, latissimus dorsi muscle strength, upper trapezius muscle strength. 
Table 4. Intraclass correlation coefficient values of the performance and strength tests

\begin{tabular}{ccc} 
& ICC & $\begin{array}{c}\text { 95\% Confidence Interval } \\
\text { (Lower Bound-Upper Bound) }\end{array}$ \\
\hline 10m sprint (s) & & $0.094-0.838$ \\
20 m sprint (s) & 0.579 & $0.350-0.904$ \\
30m sprint (s) & 0.750 & $0.339-0.932$ \\
OLH (cm) & 0.788 & $0.667-0.948$ \\
S.Flex (N) & 0.868 & $0.893-0.978$ \\
S.Ext (N) & 0.949 & $0.896-979$ \\
S.Abd (N) & 0.951 & $0.737-0.947$ \\
E.Eks (N) & 0.875 & $0.874-0.974$ \\
S.Anterior (N) & 0.940 & $0.754-0.950$ \\
L.Dorsi (N) & 0.883 & $0.829-0.965$ \\
U.Trapezius (N) & 0.919 & $0.652-0.930$ \\
\hline
\end{tabular}

ICC: Intraclass correlation coefficient, OLH: One leg hop test, S.Flex: Shoulder flexion strength, S.Ext: Shoulder extension strength, S.Abd: Shoulder abduction strength, E.Ext: Elbow extension strength, S.Anterior: Serratus anterior muscle strength, L.Dorsi: Latissimus dorsi muscle strength, U.Trapezius: Upper trapezius muscle strength.

\section{DISCUSSION}

As a result of this study, which was designed to determine the association between upper extremity strength and performance in elite amputee players, it was found that there could be an interaction between upper extremity strength and anaerobic performances of amputee players.

The overall health and life qualities of many people with physical disabilities are low [30]. Many rehabilitation programs have been developed to treat this situation. However, physical therapy and rehabilitation services cannot continue for a long time in the form of inpatient or outpatient treatment [31]. For this reason, adapted sports are increasingly used in disabled individuals as a support to physical therapy and rehabilitation [31], and there are many sports branches that emerged based on this opinion. Amputee football, one of these sportive branches, was created for recreation and rehabilitation at the beginning like most other sports branches for the disabled. Later on, it was transformed into a developing professional sports branch supported by investments and incentives [6, 7, 14].

As in regular football, lower extremity strength is one of the most important components for anaerobic performance in amputee football [15, 17, 32]. However, there may be a need for different requirements when compared to regular football in order to provide sufficient performance in amputee football, especially due to the use of crutches. With this in mind, many researchers conducted studies on upper extremities performance of amputee football players [18-20]. However, these studies did not examine the relationship between upper extremity strength and performance in amputee players specifically. In this respect, this is the first study in the literature. As a result of the analysis, it was observed that sprinting performance at 10, 20 meters associated with latissimus dorsi muscle and one leg hop performance, and 30-meter sprint with shoulder extension strength and one leg hop performance. On the contrary, there was no relation between aerobic performance and the relevant parameters. When these results were evaluated, the presence of a relationship between one leg hop and sprint performance might be an expected result. Multiple studies had already confirmed this outcome in both regular 
and amputee football players [17, 32]. However, the interesting result is to reveal the association between the upper extremity strength and performance in amputee players. The occurrence of this situation is probably due to the use of crutches. The study by Requejo et al. also verifies this result [33]. In their study, Requejo et al. examined the upper extremity kinetics in the use of crutches and stated that at the end of the crutch swing phase, the shoulder had approximately 10 degrees of abduction and 20 degrees of flexion angle and these angles turned into 0 degrees of extension and adduction at the beginning of the crutch swing phase. They also stated that 15-25 degrees of humeral internal rotation was present during these phase transitions [33]. When the crutch swing phase was analyzed completely, it was seen that there was a shoulder extension, abduction and internal rotation cycle indicating latissimus dorsi function. Latissimus dorsi muscle, which plays an important role in crutch-assisted gait and includes shoulder extension, probably plays an important role in the anaerobic performance of amputee players along with the lower extremity strength. Based on its results, this study brings new suggestions to coaches for increasing performance in amputee players.

When similar studies investigating the upper extremity effectiveness in amputee players are examined, it was observed that two studies had similar $[18,19]$, and one had opposite views to this study [20]. According to the study by Simim et al., the number of push-ups performed after the amputee football competition were decreased [19]. Miyomoto et al. noted a significant negative relationship between 30 meters sprint performance and the number of push-ups [18]. Accordingly, the results of these two studies suggested that there may be a requirement for upper extremity strength/endurance for sufficient performance in amputee football players. In contrast, Wieczorek et al. found that there was no relationship between $30 \mathrm{~m}$ sprint and hand held dynamometer strength [20]. Although the results of the research contrast with the results of this study, the authors attributed the probable cause of this outcome to the assumption that the isometric strength measured by hand dynamometer may not correspond to the nature of the sprint.

When the aerobic performance associations of amputee players were analyzed, it was seen that the results of the study were compatible with the literature. A study indicated that the main determinants of aerobic performance were maximal cardiac output and total hemoglobin mass [34]. In terms of strength, it was stated that muscle strength decreased the mitochondrial density and may reduce the endurance capacity by reducing oxidative enzyme activity [35, 36]. Therefore, aerobic performance is believed to be based on endurance rather than strength [37]. In order to determine whether the upper extremity has an effect on the aerobic performances of amputee players, evaluating the endurance instead of the strength would be a more accurate method. This is one of the limitations of the study. The second limitation is that, since the study was designed retrospectively, only the data of the players participating in the relevant camps and whose performance and strength data were complete could be analyzed. Narrow population is another limitation of the study. The results of this study represent amputee individuals playing football. In order to practice the results in sedentary amputated individuals, the study should be carried out in the relevant population. 


\section{CONCLUSIONS}

With this study, it was demonstrated that the anaerobic performances of elite amputee players may be related to the upper extremity strength. In order to increase sprinting performance in amputee football players, it is recommended that training programs should include shoulder extension, particularly latissimus dorsi strengthening exercises.

\section{REFERENCES}

[1] Simim MA, Silva BV, Marocolo Júnior M, Mendes EL, Mello MTd, Mota GR. Anthropometric profile and physical performance characteristic of the Brazilian amputee football (soccer) team. Motriz J Phys Ed. 2013;19:641-648. https://doi.org/10.1590/S1980-65742013000300016

[2] Kayssi A, de Mestral C, Forbes TL, Roche-Nagle GA. Canadian population-based description of the indications for lower-extremity amputations and outcomes. Can J Surg. 2016;59:99. https://doi. org/10.1503/cjs.013115

[3] Ziegler-Graham K, MacKenzie EJ, Ephraim PL, Travison TG, Brookmeyer R. Estimating the prevalence of limb loss in the United States: 2005 to 2050. Arch Phys Med Rehabil. 2008;89:422-429. https:// doi.org/10.1016/j.apmr.2007.11.005

[4] Horgan, O, MacLachlan M. Psychosocial adjustment to lower-limb amputation: A review. Disabil Rehabil. 2004;26:837-850. https://doi.org/10.1080/09638280410001708869

[5] Bragaru M, Van Wilgen CP, Geertzen JH, Ruijs SG, Dijkstra PU, Dekker R. Barriers and facilitators of participation in sports: a qualitative study on Dutch individuals with lower limb amputation. PLoS One. 2013;8:e59881. https://doi.org/10.1371/journal.pone.0059881

[6] Mikami Y, Fukuhara K, Kawae T, et al. Exercise loading for cardiopulmonary assessment and evaluation of endurance in amputee football players. J Phys Ther Sci. 2018;30:960-965. https://doi.org/10.1589/ jpts.30.960

[7] Aytar A, Pekyavas NO, Ergun N, Karatas M. Is there a relationship between core stability, balance and strength in amputee soccer players? A pilot study. Prosthet Orthot Int. 2012;36:332-338. https:// doi.org/10.1177/0309364612445836

[8] Auricchio JR, Bernardes N, Moreno MA. Study of the quality of life in amputee soccer players. Manual Ther Posturol Rehabili J. 2017;15:1-5. https://doi.org/10.17784/mtprehabjournal.2017.15.451

[9] Hansen N, Forchheimer M, Tate D, Luera G. Relationships among community reintegration, coping strategies, and life satisfaction in a sample of persons with spinal cord injury. Top Spinal Cord Inj Rehabil. 1998;4:56-72. https://doi.org/10.1310/GYWA-96BR-4LAJ-9K18

[10] Yazıcıoğlu K, Tahmisoğlu M. Amputee Sports for Victims of Terrorism. NATO Science for Peace and security Series. Human and Societal Dynamics. 2007;31:94-100.

[11] Yazicioglu K, Taskaynatan MA, Guzelkucuk U, Tugcu I. Effect of playing football (soccer) on balance, strength, and quality of life in unilateral below-knee amputees. Am J Phys Med Rehabil. 2007;86:800805. https://doi.org/10.1097/PHM.0b013e318151fc74

[12] Lowther J, Lane A, Lane H. Self-efficacy and psychological skills during the amputee soccer world cup. Athl Insight. 2002;4:23-34.

[13] Özkan A, Safaz İ, Yaşar E, Yazıcıoğlu, K. An examination of physical fitness related with performance characteristics of amputee football players. IntJSCS. 2014;1:66-77.

[14] Gunaydin, G. Is there a relationship between horizontal jump and sprint performance in professional amputee football players? Ann Med Res. 2019;26:2454-2458. https://doi.org/10.5455/ annalsmedres.2019.08.468

[15] Kin-Isler A, Ariburun B, Ozkan A, Aytar A, Tandogan R. The relationship between anaerobic performance, muscle strength and sprint ability in American football players. Isokinet Exerc Sci. 2008;16:87-92. https://doi.org/10.3233/IES-2008-0301

[16] Wisløff U, Castagna C, Helgerud J, Jones R, Hoff J. Strong correlation of maximal squat strength with sprint performance and vertical jump height in elite soccer players. Br J Sports Med. 2004;38:285288. https://doi.org/10.1136/bjsm.2002.002071

[17] Özkan A, Kayıhan G, Köklü Y, Ergun N, Koz M, Ersöz G, Dellal A. The relationship between body composition, anaerobic performance and sprint ability of amputee soccer players. J Hum Kinet. 2012;35:141-146. https://doi.org/10.2478/v10078-012-0088-3

[18] Miyamoto A, Maehana H, Yanagiya T. Characteristics of anaerobic performance in Japanese amputee soccer players. Juntendo Medical Journal. 2018;64:22-26. https://doi.org/10.14789/jmj.2018.64. JMJ18-P11

[19] Simim, MA, da Mota GR, Marocolo M, da Silva BV, de Mello MT, Bradley PS. The demands of amputee soccer impair muscular endurance and power indices but not match physical performance. Adapt Phys Act Q. 2018;35:76-92. https://doi.org/10.1123/apaq.2016-0147

[20] Wieczorek M, Wiliński W, Struzik A, Rokita A. Hand grip strength vs. sprint effectiveness in amputee soccer players. J Hum Kinet. 2015;48:133-139. https://doi.org/10.1515/hukin-2015-0099

[21] Noyes FR, Barber SD, Mangine RE. Abnormal lower limb symmetry determined by function hop tests after anterior cruciate ligament rupture. Am J Sports Med. 1991;19:513-518. https://doi. org/10.1177/036354659101900518 
[22] Ross MD, Langford B, Whelan PJ. Test-retest reliability of 4 single-leg horizontal hop tests. J Strength Cond Res. 2002;16:617-622. https://doi.org/10.1519/00124278-200211000-00021

[23] Leger LA, Mercier D, Gadoury C, Lambert J. The multistage 20 metre shuttle run test for aerobic fitness. J Sports Sci. 1988;6:93-101. https://doi.org/10.1080/02640418808729800

[24] Kume D, Iguchi A, Endoh H. Accelerated point of muscle deoxygenation during the 20-m shuttle run test. Clin Physiol Funct Imaging. 2018;38:390-395. https://doi.org/10.1111/cpf.12426

[25] Vannebo KT, Iversen VM, Fimland MS, Mork PJ. Test-retest reliability of a handheld dynamometer for measurement of isometric cervical muscle strength. J Back Musculoskelet Rehabil. 2018;31:557565. https://doi.org/10.3233/BMR-170829

[26] Dallmeijer AJ, Baker R, Dodd KJ, Taylor NF. Association between isometric muscle strength and gait joint kinetics in adolescents and young adults with cerebral palsy. Gait Posture. 2011;33:326-332. https://doi.org/10.1016/j.gaitpost.2010.10.092

[27] Hislop H, Avers D, Brown M. Daniels and Worthingham's muscle testing: techniques of manual examination. 1st ed. USA: Elsevier Health Sciences; 2013, 79-170.

[28] Celik D, Dirican A, Baltaci G. Intrarater reliability of assessing strength of the shoulder and scapular muscles. J Sport Rehabil. 2012;21:1-5. https://doi.org/10.1123/jsr.2012.TR3

[29] Hair JF, Black WC, Babin BJ Anderson RE. Multivariate data analysis: A global perspective. New Jersey: Pearson Prentice Hall; 2010.

[30] Rimmer JH, Riley B, Wang E, Rauworth A, Jurkowski J. Physical activity participation among persons with disabilities: barriers and facilitators. Am J Prev Med, 2004;26:419-425. https://doi.org/10.1016/j. amepre.2004.02.002

[31] Yazicioglu K, Yavuz F, Goktepe AS, Tan AK. Influence of adapted sports on quality of life and life satisfaction in sport participants and non-sport participants with physical disabilities. Disabil Health J. 2012;5:249-253. https://doi.org/10.1016/j.dhjo.2012.05.003

[32] Arslan C. Relationship between the 30-second Wingate test and characteristics of isometric and explosive leg strength in young subjects. J Strength Cond Res. 2005;19:658. https://doi. org/10.1519/14533.1

[33] Requejo PS, Wahl DP, Bontrager EL, et al. Upper extremity kinetics during Lofstrand crutch-assisted gait. Med Eng Phys. 2005;27:19-29. https://doi.org/10.1016/j.medengphy.2004.08.008

[34] Lundby C. Robach P. Performance enhancement: what are the physiological limits? Physiology. 2015;30:282-292. https://doi.org/10.1152/physiol.00052.2014

[35] Nelson AG, Arnall DA, Loy SF, Silvester LJ, Conlee RK. Consequences of combining strength and endurance training regimens. Phys Ther. 1990;70:287-294. https://doi.org/10.1093/ptj/70.5.287

[36] Sale DG, MacDougall JD, Jacobs I, Garner S. Interaction between concurrent strength and endurance training. J Appl Physiol. 1990;68:260-270. https://doi.org/10.1152/jappl.1990.68.1.260

[37] Knuttgen HG, Strength training and aerobic exercise: comparison and contrast. J Strength Cond Res. 2007;21:973-978. https://doi.org/10.1519/00124278-200708000-00053 